\title{
Two turbellarians parasitic in fish
}

\author{
L. R. G. Cannon ${ }^{1}$, R. J. G. Lester ${ }^{2}$ \\ ${ }^{1}$ Queensland Museum, Queensland Cultural Centre, PO Box 300, South Brisbane, Queensland 4101, Australia \\ ${ }^{2}$ Department of Parasitology, University of Queensland, St Lucia, Brisbane, Queensland 4067, Australia
}

\begin{abstract}
Marine fishes, Scarus rivulatus (Scaridae) from the Great Barrier Reef, and Platycephalus fuscus (Platycephalidae) and Pelates quadrilineatus (Theraponidae) from southern Queensland, were found infected with parasitic turbellarians which encysted in the skin or gills. These worms caused minor pathological changes by creating tunnels or pockets in the dermis and epidermis. Those from the parrot fish S. rivulatus were identified as Ichthyophaga sp. (Prolecithophora) and those from the other fishes as Paravortex sp. (Rhabdocoela). A table of turbellarians recorded from vertebrate hosts is included
\end{abstract}

\section{INTRODUCTION}

Turbellarian worms are predominantly free-living members of the Platyhelminthes and, although parasitic and commensal members are scattered through the group (Jennings 1971), very few are known to be associated with vertebrates. One, Bdellasimilis barwicki - an aberrant triclad in the family Procerodidae lives in the limb pits of freshwater turtles in Australia (Richardson 1968, 1970, Ball 1976) where it feeds as an ectosymbiotic predator or an opportunistic commensal (Jennings 1985). All other known turbellarians are from fish, e.g. Micropharynx parasitica (Procerodidae) lives firmly attached to the dorsal skin of rays (Elasmobranchii) from the northern Atlantic and the Bering Sea (Jägerskiöld 1896, Awerinzew 1925, Ball \& Khan 1976) and Procerodes lobata has been associated with lesions on the surface of various fishes from the Mediterranean (Wilhelmi 1909, Vogt 1891). Furthermore, a proseriate, Digenobothrium inerme, was described in Europe from the surface of young eels (Leptocephalus) by Palombi (1926), but until recently only one turbellarian had been considered a true parasite, viz. Ichthyophaga subcutanea, a prolecithophoran (F. Urastomidae) described from cysts on the skin and fins of the marine fishes Bero and Hexagrammus from the Sea of Japan by Syromjatnikova (1949) and recorded also from the gill connective tissue of a tropical reef fish, Cephalopholis pachycentron (Serranidae), by Menitskii (1963). Over the past decade there have been several accounts of a turbellarian causing lesions on various marine aquarium fish from the Pacific and the Caribbean (Blasiola 1976,
Condé 1976). This has been called the tang turbellarian by Kent (1981) because of its prevalence on the acanthurid fish Zebrasoma flavescens, the yellow tang. Kent \& Olson (1980) had likened it to Ichthyophaga, but Kent \& Olson (1986) claim it to be a species of Paravortex (Rhabdocoela: Graffillidae).

In 1984 we obtained specimens of turbellarians from fishes of the Great Barrier Reef and from southern Queensland. These specimens were enclosed in shallow epidermal pockets (Cannon \& Lester 1986). Attemps to obtain more material of the worms have not been successful, thus an account of the infestations is now presented to bring attention to these phenomema which may be confused with immature trematode infections.

\section{MATERIALS AND METHODS}

A Scarus rivulatus specimen was fixed immediately after capture in $10 \%$ formalin. Platycephalus fuscus and Pelates quadrilineatus specimens were kept in aquaria at $20^{\circ} \mathrm{C}$ for 1 and $21 \mathrm{~d}$ respectively prior to dissection. Tissues and worms were similarly fixed in $10 \%$ formalin and embedded in paraffin, sectioned at 6 to $8 \mu \mathrm{m}$ and stained in haematoxylin and eosin. All are in the Queensland Museum (QM) and in the following (S) indicates sections. Drawings and measurements were made with the aid of a camera lucida.

Material examined. Ichthyophaga: QM GL4800-3 (S), ex one Scarus rivulatus, length $70 \mathrm{~mm}$, Pandora Reef, GBR, coll. P. Doherty, 5 April 1984. 
Paravortex: QM GL4804 (S), ex cephalic skin of one Platycephalus fuscus, length $202 \mathrm{~mm}$, Woody Pt, Moreton Bay, Queensland, coll. C. Boel, 8 May 1984, gravid adult coll. R. Lester; QM GL4805-7 (S), juveniles, same data as adult; QM4808 (S), ex gill pouch on one Pelates quadrilineatus, length $96 \mathrm{~mm}$, Woody $\mathrm{Pt}, 15 \mathrm{March}$ 1984, gravid adult coll. R. Lester

\section{RESULTS}

\section{Ichthyophaga sp. (O. Prolecithophora, F. Urastomidae)}

Parasite morphology

All 3 worms recovered from the skin of the parrot fish were ovoid, about $1000 \mu \mathrm{m} \times 300 \mu \mathrm{m}$, and ciliated (Fig. 1). The body wall is thin, but the cilia are long (30 to 50 $\mu \mathrm{m}$ ) and coated with an eosinophilic secretion (Fig. 2) causing them to appear as a solid band in sections. The body wall musculature is poorly doveloped, and parenchyma hardly differentiated from the gut. Anteriorly a cluster of large hyaline (poorly staining) cells form a cone at the anterior end; a cerebral ganglion lies at the posterior edge of the cone and a pair of large eyespots flank the ganglion. Each eyespot resembles a clover leaf of fine brown/black granules about a hyaline cone made of 3 lens elements abutted at $120^{\circ}$ (Fig. 1c). Posteriorly there is a globular, muscular pharynx (Fig. 1a) about $60 \mu \mathrm{m}$ in diameter in a shallow buccal cavity with a terminal mouth through which the pharynx may protrude. Proximally the pharynx contains numerous glands, and further several large glands - their bodies in the posterior body-drain to the oesophageal region. The body is tilled with a saccate gut win a smail central lumen containing cells reminiscent of host epithelial cells. The gastrodermis is filled with small inclusions, presumably the remains of these cells, and numerous fine black pigment granules and clusters.

\section{lchthyophaga sp.}
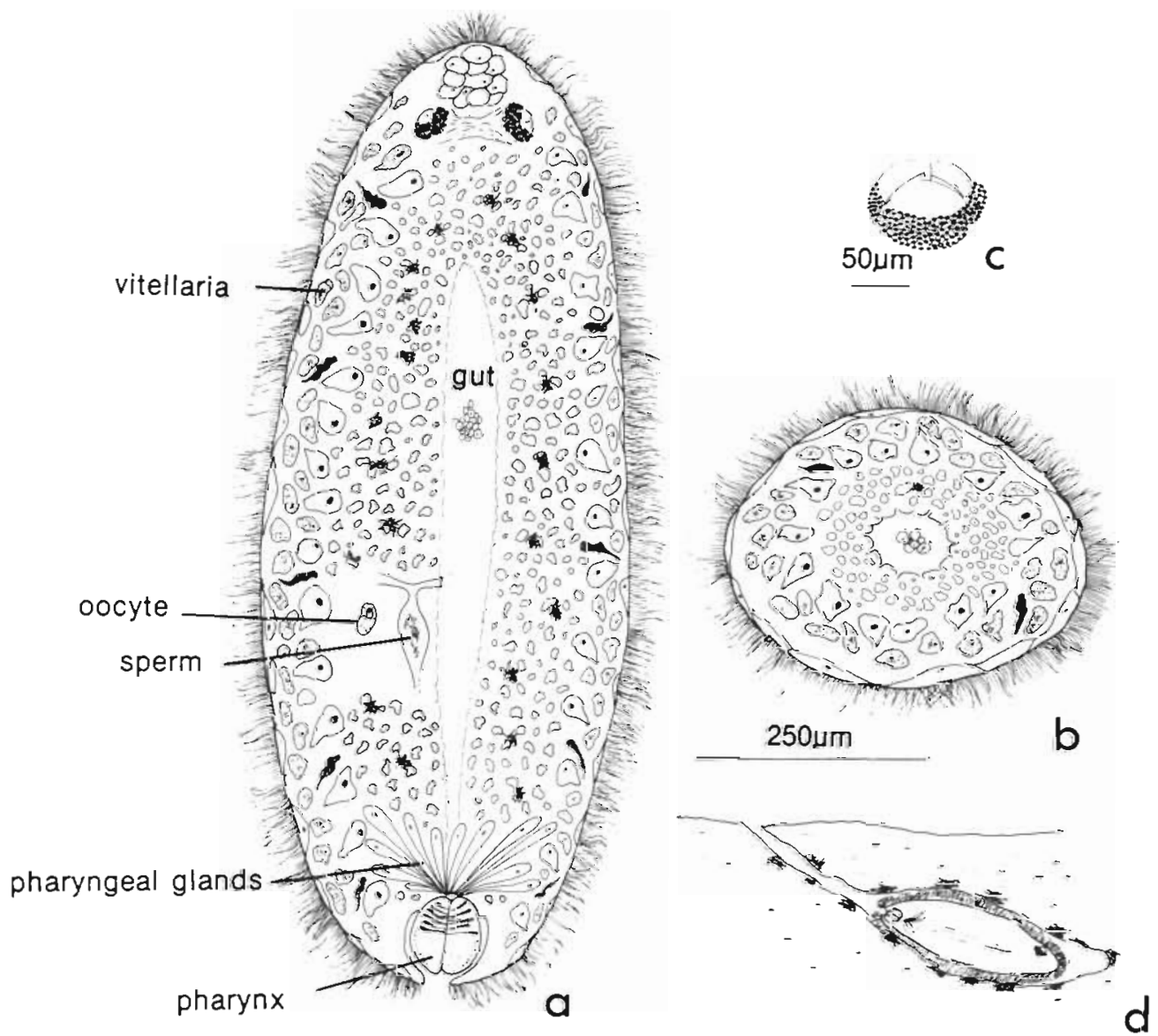

worm in dermal tunnel

Fig. 1. Ichthyophaga sp. from 'rysts' on body surface and fins of Scarus rivulatus. (a) Whole worm; (b) transverse section; (c) details of eyespot: (d) worm in situ (not to scale) 


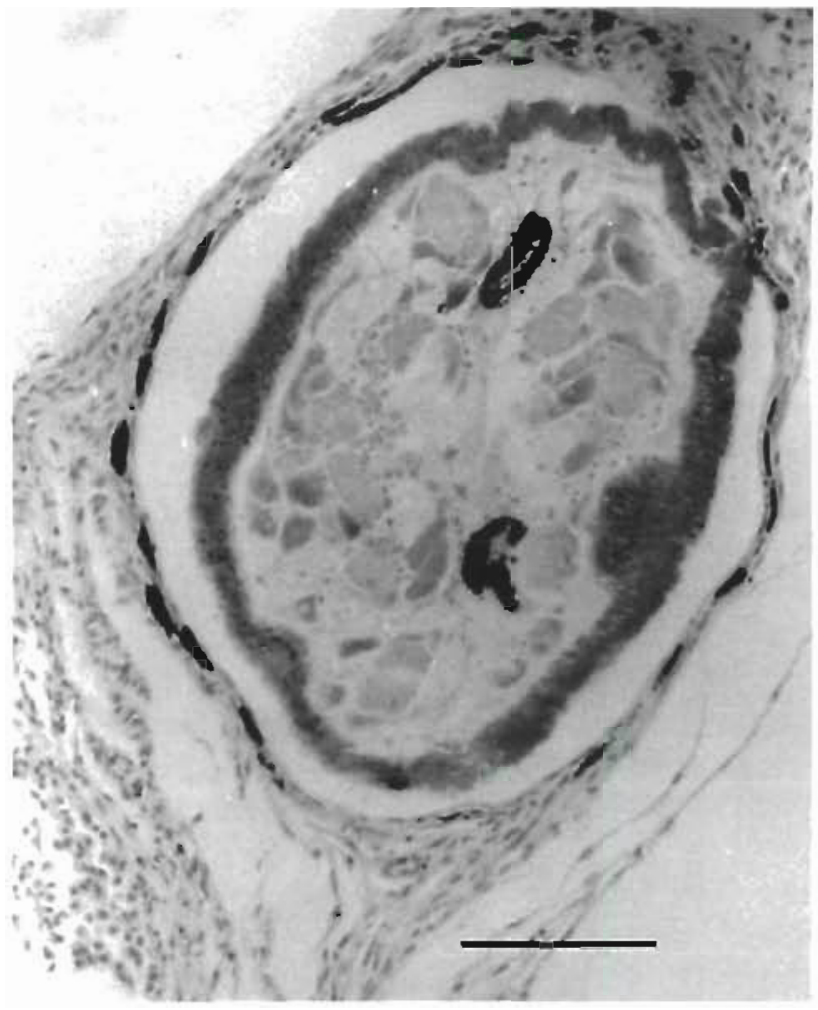

Fig. 2. Ichthyophaga sp. Photomicrograph of transverse section in region of eyespots: note dense band of cilia, and melanophores lining chamber Scale bar $=75 \mu \mathrm{m}$

The cells of the gastrodermis are very weakly differentiated giving the appearance of a syncitium and are hardly separated from the surrounding parenchyma (Fig. 1b).

Peripherally the body is filled with large cells: large refractory cells filled with fine granulations. Slightly smaller but more numerous are cells staining deeply with haematoxylin (vitellaria) and occasional small gland cells which are deeply eosinophilic. Ovaries were not seen, though in one worm a small oocyte was seen in the lateral parenchyma. Neither were testes seen, but in the mid ventral body 2 fine ducts were seen to coalesce to form a weakly muscled, posteriorly directed tube that was filled with a sperm bolus about $40 \mu \mathrm{m}$ in diameter. Neither a male copulatory bulb nor ducts to the buccal region were seen.

\section{Host pathology}

Worms were found in Scarus rivulatus in the skin of the ventral abdomen and of the anal and pelvic fins and were not associated with any clinical disease. They were in dark 'cysts' resembling those caused by metacercariae of Digenea (Fig. 3). Of 5 cysts dissected,

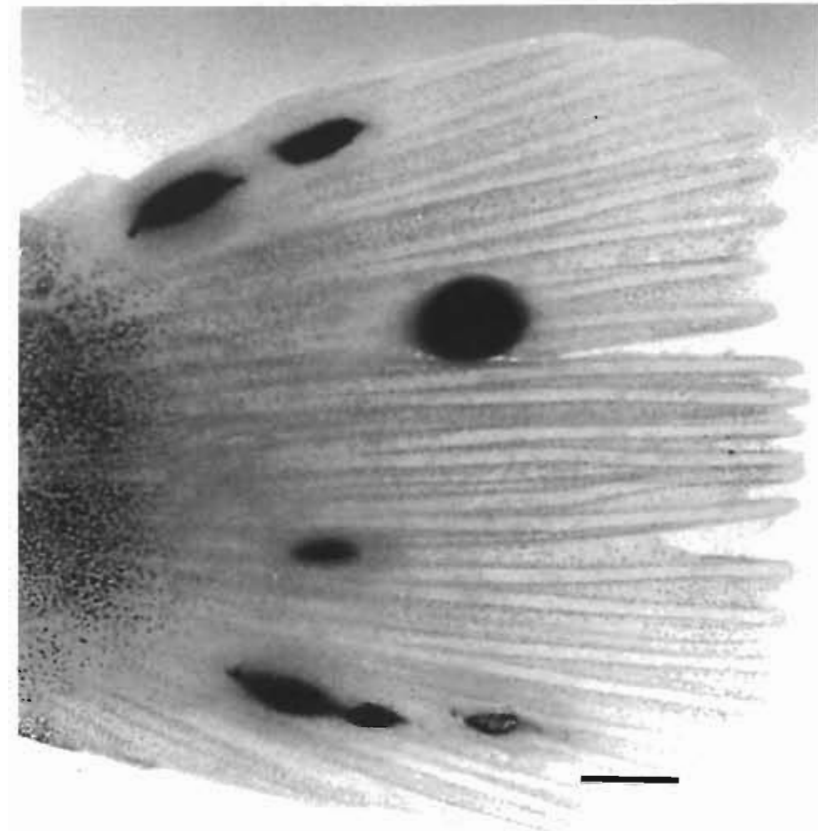

Fig. 3. Scarus rivulatus. Tail with melanised 'cysts' containing Ichthyophaga sp. Scale bar $=1 \mathrm{~mm}$

3 contained 1 worm each and 2 appeared to be empty.

Cysts were in the upper layers of the dermis. The cyst wall was composed of loose fibrous tissue and scattered melanocytes. In 2 cysts examined histologically, worms occupied the centre of the cavity (Fig. 2) and canals extended a short distance into the dermis at either end giving the cysts a pointed appearance (Fig. 3). In these sections it was not clear whether or not the canals opened to the surface. A third cyst sectioned had 2 canals ending blindly in the dermis and a third canal, adjacent to the pharynx, which passed through the dermis and epidermis and opened at the surface. Leucocytic infiltration was evident in the dermis. The gut of the worms contained cells and black pigment granules similar to those lining the wall of the chamber and canals

In all, 8 cysts were found on the one fish. Similar cysts were seen on other Scarus rivulatus at Pandora Reef, but no other specimens were made available to us for study.

\section{Paravortex sp. (O. Rhabdocoela, F. Graffillidae)}

Three gravid worms were found, one on the gill of Pelates quadrilineatus and two in the head canals of a Platycephalus fuscus, one beneath the eye and one at the posterior of the cranium. Several juveniles were also present in the canal beneath the eye. During removal, the worm on the cranium burst releasing 100 
to 200 young Both fish were from Moreton Bay in southern Queensland.

\section{Parasite morphology}

Both adult worms were spindle-shaped and cream or yellow, measuring about $2500 \times 750 \mu \mathrm{m}$. The body is completely ciliated, with cilia 5 to $6 \mu \mathrm{m}$ long. The body wall is thin and packed with small eosinophilic granules (rhabdites?); parenchyma and musculature are poorly developed (Fig. 4a, b). Anteriorly 2 pairs of large glands, the bodies of which lie behind the pharynx, discharge at the apex. Near the anterior dorsal surface lies a cerebral ganglion flanked by a pair of prominent eyespots. Each eyespot has a cloverleaf cluster of large/ coarse black or brown granules enclosing a cone consisting of 3 hyaline lenses arranged at $120^{\circ}$. The mouth is subterminal at the anterior and opens to a small buccal cavity. The pharynx is muscular, about $200 \times 120 \mu \mathrm{m}$, and slightly broader posteriorly where it contains numerous glands. The pharynx is capable of dramatic protrusion. Immediately behind the pharynx is a cluster of oesophageal cells and then a large saccate gut extends back in the dorsal body to the posterior end of the body. The gastrodermis is poorly defined and filled with hyaline granules or 'excretory spheres'.

A common genital pore opens midventrally in the second quarter of the body. Because only juvenile and

\section{Paravortex $s p$.}

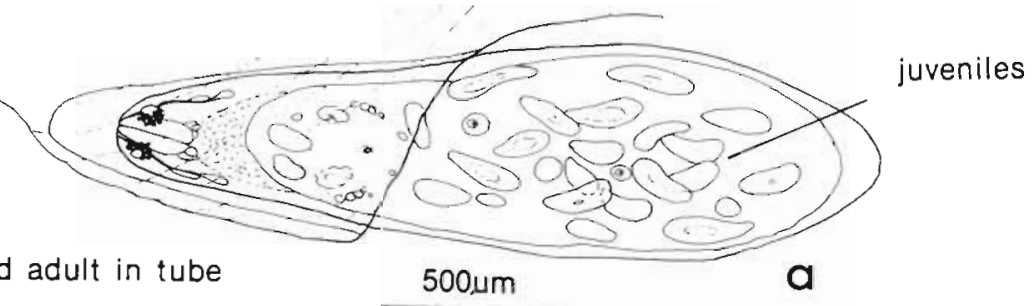

gravid adult in tube

500 um

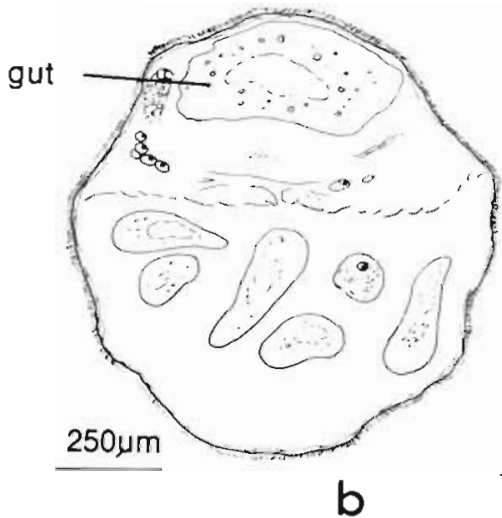

b

T.S. gravid adult

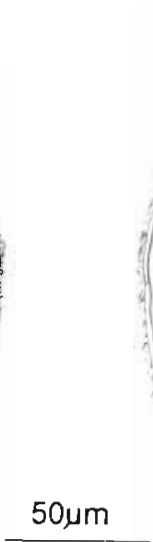

\section{$500 \mathrm{~m}$}

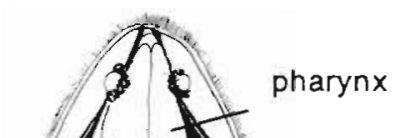

\section{-}
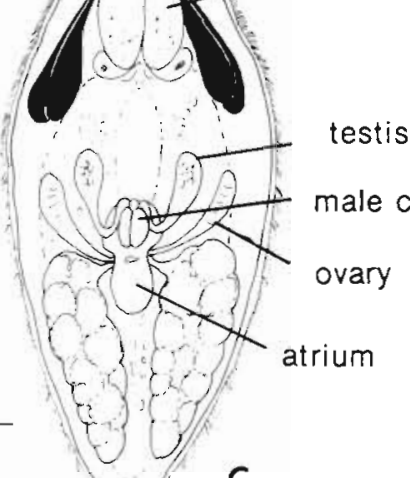

testis

I male copulatory bulb

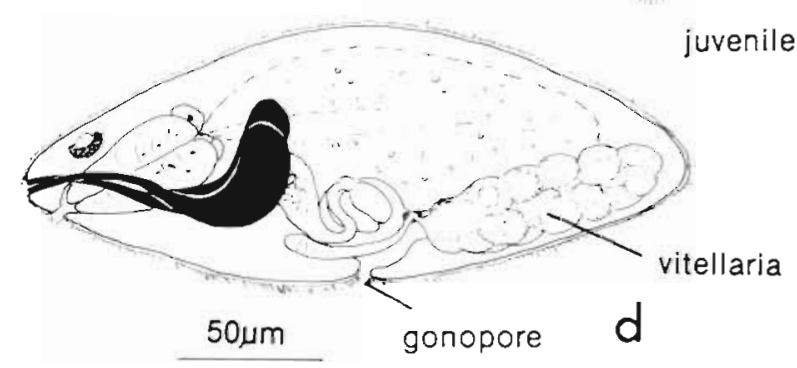

c

atrium 
extremely gravid individuals have been observed the reproductive morphology of mature, non-gravid adults is not known.

Gravid adults. (Fig. 4a, b). Here the gonopore has disappeared, though a slight thickening of the ventral body wall is discernible, and the atrium is now a commodious space filling nearly all of the ventral body from just behind the pharynx to the tail. A muscular septum separates it from the remainder of the parenchyma. This space is filled with ova, embryos and developing worms, but in the material available there was no evidence of twinning. The testes and ovaries are reduced to remnants - clusters of cells now pushed high in the body to the dorso-lateral wall with poorly developed ducts remaining. The vitellaria are not evident, but remnants of oviducts and vitelline ducts remain above the muscle septum where too a slight thickening probably represents the remains of a penis bulb.

Juveniles. About 200 um long (Fig. 4c, d), these have the gonopore in the middle of the ventral surface. The gonopore opens into a common atrium with a small but distinct posterior extension. At about the point where the extension begins the oviduct and the vitelline duct appear to join the atrium through a small dorsolateral sphincter. The small paired ovaries lie laterally and just anterior to the atrium; extensive vitellaria fill the sides of the body from the gonopore to the tail with a series of morula-like structures enclosed in a tunica. Small paired testes lie just anterior and more central than the ovaries; from the testes strongly curved ducts loop posteriorly and dorsally to join at the proximal position of a small muscular unarmed penis which protrudes into the atrium from the anterior dorsal wall. Swollen epidermal cells are present in juveniles, especially anteriorly. Juveniles, both when within the parent and when free, may extend up to about $500 \mu \mathrm{m}$ in length. Even at this young stage the pharynx is protrusible.

\section{Host pathology}

The orange-yellow worms on the gill and head were partly enclosed by a translucent tube of fish tissue and were not easily dislodged (Fig. 5). The posterior of the worms pulsated in and out of the open end of the tube on both fish species. Histological sections were only available for the infection in Pelates quadrilineatus. The worm lay along a gill filament within a tube composed of layers of epithelial cells (Fig. 6). Part of the wall of the tube contained flattened gill lamellae. The tube ended in epithelial tissue and it was presumably on this that the worm fed. No necrosis was evident and there was little inflammatory response. The effect of the infection on the fish appeared to be the loss of lamellar function and stimulation of epithelial hyper-

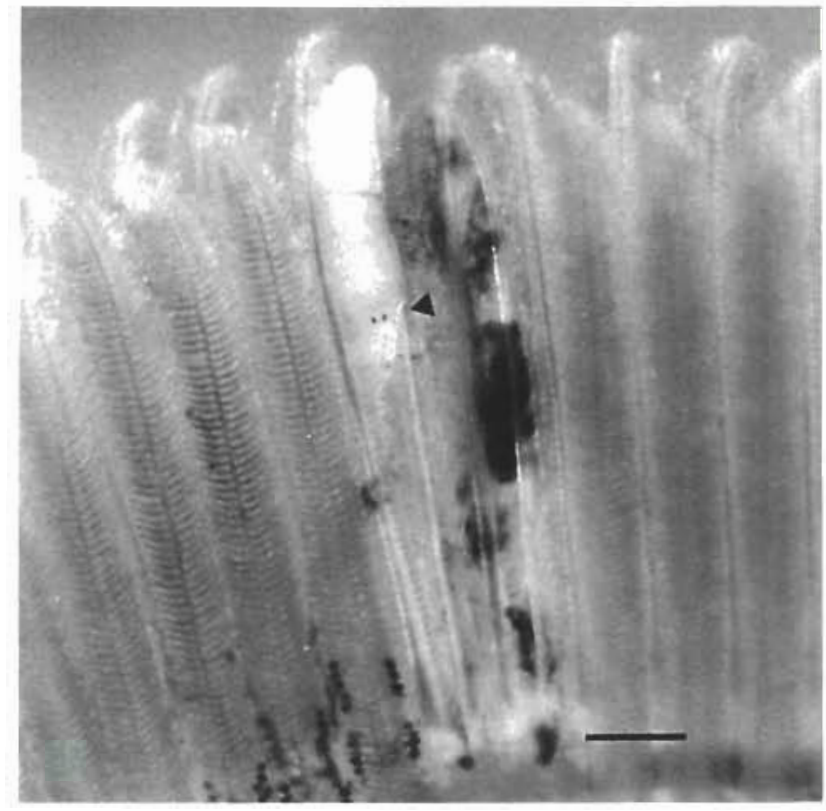

Fig. 5. Pelates quadrilineatus. Part of gill showing partially enclosed Paravortex sp. in an epithelial tube. Arrow indicates eyespots of worm. (The haemorrhagic tissue to the right is an artifact). Scale bar $=1 \mathrm{~mm}$

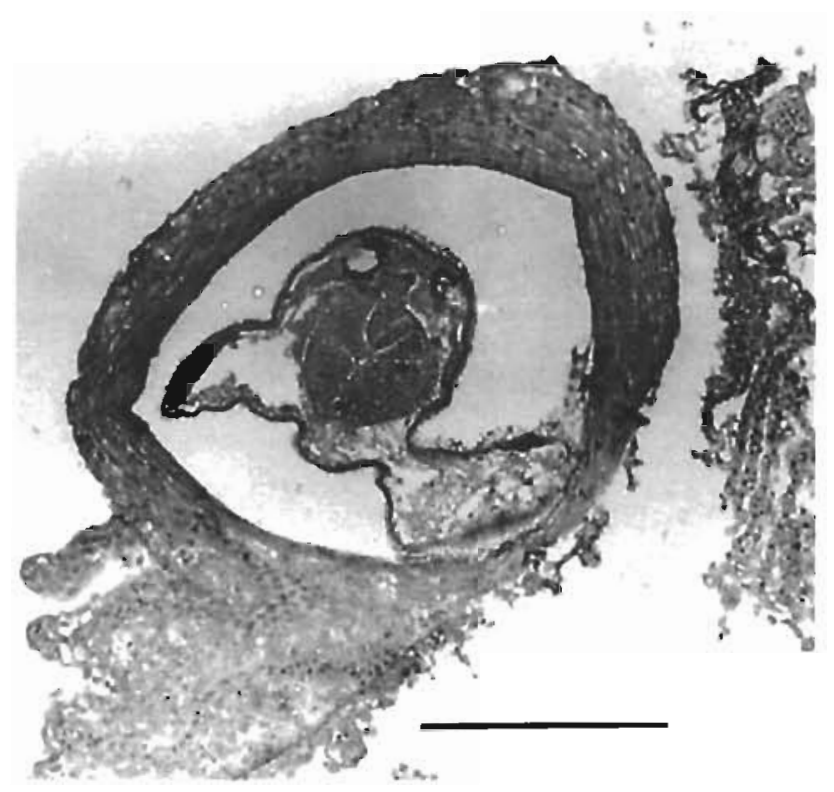

Fig. 6. Paravortex sp. Photomicrograph of transverse section within gill tube in region of eyespots: note pharynx. Scale $=$ $150 \mu \mathrm{m}$

plasia that covered the non-functioning lamellae and most of the worm.

No worms were found in an additional 100 Pelates quadrilineatus and 20 Platycephalus fuscus examined from the same area 


\section{DISCUSSION}

Determination of the identity of turbellarians has been made easier by the publication of Cannon's (1986) guide; however, worms which are not fully mature (or those excessively gravid) still present problems. Features such as the form of the oocytes and/or vitellaria and nature of the pharynx are critical for ordinal determinations, and recognition of families or genera generally depends upon details of the mature reproductive system.

Although the Ichthyophaga sp. were all largely immature, it is clear that vitelline cells without a tunica are scattered about the periphery of the body and oocytes are also apparently free. These observations indicate that the worms belong to the Prolecithophora. The posterior pharynx places the worm in the Urastomidae which has only 2 genera, viz. Urastoma with a muscular penis bulb and which is found free or associated with bivalve gills (Westblad 1955, Flemming et al. 1981), and Ichthyophaga lacking the penis bulb and found in 'cysts' in the skin and gills of marine fishes (Syromjatnikova 1949, Menitskii 1963). Clearly the present worm lies in the genus Ichthyophaga which contains the single species subcutanea. It differs from subcutanea as described by Syromjatnikova (1949) and more closely resembles that described by Menitskii (1963). Menitskii examined Syromjatnikova's material and reported several discrepancies between her material and her description. He concluded his material was of the same species though coming from the gills of a tropical reef fish. I. subcutanea was described as having entolecithal eggs or germovitellaria. This appears to be a misinterpretation and indeed the figures of this species show it to resemble the present species very closely with regard to the peripheral cell architecture. In all cases relatively few specimens were available for study. Until more material is on hand we hesitate to assign the present worm to subcutanea.

Grizzle \& Williams (1985) illustrated a worm in a section of a melanistic cyst from a tropical reef fish from Puerto Rico. They gave no details, but did state it was a turbellarian. It appears most similar to the sections we have of Ichthyophaga sp.

Mature but non-gravid paravortex were not available for study. The presence of distinct vitellaria contained within a tunica, however, together with other characteristics - especially an anterior pharynx doliiformis - clearly indicate the worm is a rhabdocoel in the family Graffillidae. Though it was not possible to determine the nature of the prostatic tissue which Marcus (1954) used to determine subfamilies, the presence of paired ovaries does convincingly indicate that the worm belongs to the Graffillinae. Furthermore the ab- sence of any indication of a seminal receptacle places the worm in Paravortex rather than Graffilla. Paravortex contains 4 species parasitic or commensal with bivalve molluscs, viz. $P$. cardii, $P$. karlingi, $P$. scrobiculariae and $P$. gemellipara. The first 3 are known from the gut and gills of bivalves around Britain and from the Mediterranean; P. gemellipara occurs on the gills of bivalves from the east coast of the USA (Wardle 1980) and Canada (Flemming et al. 1981). A further unnamed species was described from the surface of fish by Kent \& Olson (1986). They gave few morphological details of the worms, but merely stated it had been identified as a species of Paravortex. This worm, quite contrary to the one from Australia, erodes the surface of the fish with its pharynx causing lesions. It does this while still immature and leaves the host to become a gravid adult on the sea floor.

The present species of Paravortex becomes the second rhabdocoel parasite of a vertebrate. The lack of twinning (usually characteristic of Paravortex) is perhaps of little significance as the capsules about the young of other species of Paravortex are known to disappear as the juveniles mature within the parent.

Protandry seems evident in Ichthyophaga and Ball (1916) commented upon the protandry of Paravortex gemellipara. It is likely that definitive diagnoses based on adult morphology will depend upon obtaining worms at a particular period of their development. Few descriptions of these worms appear in the literature. Comparisons have been possible, however, though we believe that until mature but non-gravid worms are available for study insufficient data exist to justify the erection of new names for these species parasitic in fish. Table 1 gives the details of species of turbellarian that associate with vertebrates.

The evidence suggests that Ichthyophaga may leave the fish to mate and disperse young. Protandry is evident, but in both species egg capsules or developing young are not known, nor indeed is it logical that the worms self-fertilize within their tunnels. A free period is indicated and certainly Urastoma is known from both symbiotic and freeliving forms (Marcus 1951, Westblad 1955). The presence of well-developed eyespots supports the hypothesis that a free period occurs during which the eyespots enable the appropriate phototactic responses to occur, perhaps to take the animal to the sediments to find shelter and a mate. Burt \& Bance (1981) claim Urastoma cyprinae exhibits a marked negative phototaxis when removed from its bivalve host. The penetration into the host's skin and the production of a home tunnel may rely on glands, but perhaps the cone of cells anteriorly may serve to allow the worm to push between cell layers. The presence of melanocytes lining the tunnels suggests these spaces last several weeks or months and to keep them open 
Table 1. Turbellarians symbiotic with vertebrates

\begin{tabular}{|c|c|c|c|c|}
\hline Worm & Habitat & Host & Locality & Authority \\
\hline \multicolumn{5}{|l|}{ O. Prolecithophora } \\
\hline \multirow[t]{3}{*}{ Ichthyophaga subcutanea } & Below skin & Bero elegans (Cottidae) & Sea of Japan & Syromjatnikova (1949) \\
\hline & & $\begin{array}{l}\text { Hexagrammus decagrammus } \\
\text { (Cottidae) }\end{array}$ & Sea of Japan & Syromjatnikova (1949) \\
\hline & In gills & $\begin{array}{l}\text { Cephalopholis pachycentron } \\
\text { (Serranidae) }\end{array}$ & $?$ & Menitskii (1963) \\
\hline Ichthyophagasp. & $\begin{array}{l}\text { In tunnels } \\
\text { in skin }\end{array}$ & Scarus rivulatus (Scandae) & GBR & Present account \\
\hline $\begin{array}{l}\text { Ichthyophaga? sp. } \\
\text { (Urastomidae) }\end{array}$ & In skin & $\begin{array}{l}\text { Holocanthus tricolor } \\
\quad \text { (Pomacanthidae: Teleostei) }\end{array}$ & Puerto Rico & Grizzle \& Williams (1985) \\
\hline $\begin{array}{l}\text { O. Proseriata } \\
\text { Digenobothrium inerme } \\
\quad \text { (Monocelididae) }\end{array}$ & On skin & $\begin{array}{l}\text { Larva of eel ('Leptocephalus') } \\
\text { (Anguillidae: Teleostei) }\end{array}$ & Europe & Palombi (1926) \\
\hline \multicolumn{5}{|l|}{ O. Tricladida } \\
\hline \multirow{3}{*}{$\begin{array}{l}\text { Bdellasimilis barwicki } \\
\text { (Procerodidae) }\end{array}$} & In limb pits & Chelodina longicollis & Australia & Richardson (1968) \\
\hline & & Emydura macquarii & Australia & Ball (1976) \\
\hline & & $\begin{array}{l}\text { Elseya dentata } \\
\text { (Cheloniidae: Reptilia) }\end{array}$ & Australia & $\begin{array}{l}\text { Richardson (1970), } \\
\text { Jennings (1985) }\end{array}$ \\
\hline \multirow{4}{*}{$\begin{array}{l}\text { Micropharynx parasitica } \\
\text { (Procerodidae) }\end{array}$} & On dorsal skin & Raja batis & Kattegat & Jägerskiöld (1986) \\
\hline & & R. clavata & Kattegat & Jägerskiöld (1896) \\
\hline & & R. radiata & Barents Sea & Awerinzew (1925) \\
\hline & & $\begin{array}{l}\text { R. radiata } \\
\quad \text { (Rajidae: Elasmobranchii) }\end{array}$ & Grand Banks & Ball \& Kahn (1976) \\
\hline $\begin{array}{l}\text { Procerodes lobata } \\
\text { (Procerodidae) }\end{array}$ & ? On skin & $\begin{array}{l}\text { Various spp. of teleost, e.g. } \\
\text { Coris (Labridae) } \\
\text { Solea (Soleidae) } \\
\text { Conger (Congridae: Teleostei) }\end{array}$ & Mediterranean & Wilhelmi (1909), Vogt (1891) \\
\hline \multicolumn{5}{|l|}{ O. Rhabdocoela } \\
\hline \multirow[t]{4}{*}{$\begin{array}{l}\text { Paravortex sp. } \\
\text { 'Tang turbellarian' }\end{array}$} & On skin & $\begin{array}{l}\text { Various tropical teleosts, e.g. } \\
\text { Zebrasoma flavescens and }\end{array}$ & Hawaii & Kent \& Olson $(1980,1986)$ \\
\hline & & Z. veliferum (Acanthuridae) & Hawaii & Kent (1981). \\
\hline & & also Pomacanthidae and & Hawaii & Blasiola (1976) \\
\hline & & Labridae and Scaridae & Caribbean & Condé (1976) \\
\hline \multirow[t]{2}{*}{$\begin{array}{l}\text { Paravortex sp. } \\
\text { (Graffillidae) }\end{array}$} & $\begin{array}{l}\text { In pouches } \\
\text { on skin and }\end{array}$ & $\begin{array}{l}\text { Platycephalus fuscus } \\
\text { (Platycephalidae) }\end{array}$ & $\begin{array}{l}\text { Moreton Bay, } \\
\text { Queensland }\end{array}$ & Present account \\
\hline & gills & $\begin{array}{l}\text { Pelates quadrilineatus } \\
\text { (Theraponidae: Teleostei) }\end{array}$ & $\begin{array}{l}\text { Moreton Bay, } \\
\text { Queensland }\end{array}$ & Present account \\
\hline
\end{tabular}

the worm would need to regularly extend into them. The strong protrusible pharynx and the presence in the gut of cells and melanin granules strongly suggest the worms feed on host cells lining the chamber.

The presence of eyespots in Paravortex again suggests phototactic responses. Pike \& Burt (1981) indicate $P$. karlingi is negatively phototactic as an adult and when gravid, but $P$. cardii initially showed positive phototaxis when a freshly escaped juvenile. This became negative after dark acclimation. Quite probably the photacitic response varies with the stage of development in order to maximize the opportunities to find suitable habitats. These worms also appear to feed on host tissue. Jennings \& Phillips (1978) and Jennings (1981) showed that $P$. scrobiculariae relied on host enzymes to aid with digestion. This would appear not to be the case with the present species, but the nature of the similar 'excretory spheres' needs investigation.
The pharynx is obviously highly mobile and protrusible and presumably is used to gather food from the host epithelium. The nature of the tube about the worm on the gill suggests the relationship is not as long-term as in Ichthyophaga.

Both species raise many questions concerning the biology of these worms and of their relationships with their hosts and the pathological effects produced. How long is the stage away from the fish and is it possible that a mollusc is involved with either species? To what extent have melanistic cysts on the gills or surface of fishes been ascribed to digenean metacercariae when in fact turbellarians have been the cause?

Acknowledgements. We thank Dr P. Doherty, Griffith University, Queensland, for first bringing the Ichthyophaga to our attention and Prof. J. H. Choat, James Cook University of North Queensland, for identification of the parrot fish host. Mr C. Boel collected the fishes from Moreton Bay and the stu- 
dents of PA305 at the University of Queensland have been responsible for seeking further specimens of Paravortex. Histological work was performed by Mr N. Hall, Queensland Museum, and Mr J. Mines, University of Queensland.

\section{LITERATURE CITED}

Awerinzew, S. (1925). Über eine neue Art von parasitierten Tricladen. Zool. Anz. 64: 81-84

Ball, S. C. (1916). The development of Paravortex gemellipara. J. Morph. 27: 453-557

Ball, I. R. (1976). Observations on Bdellasimilis barwicki, a marine triclad from Australian freshwaters (Platyhelminthes: Turbellaria). Aust. Zool. 19: 95-101

Ball, I. R., Khan, R. A. (1976). On Micropharynx parasitica Jägerskiöld, a marine planarian ectoparasitic on thorny skates, Raja radidala Dunuvall, from the North Atlantic Ocean. J. Fish. Biol. 8: 419-426

Blasiola, G. C. (1976). Ectoparasitic turbellaria. Mar. Aquarist. 7. $53-58$

Burt, M. D. B., Bance, G. W. (1981). Ultrastructure of the eye of Urastoma cyprinae. Hydrobiologia 84: 276

Cannon, L. R. G. (1986). Turbellaria of the world. Queensland Museum, South Brisbane

Cannon, L. R. G., Lester, R. J. G. (1986). Two turbellarians parasitic in fish. In: Howell, M. J. (ed.) Parasitology - quo vadit? Handbook Proc. VIth Internat. Cong. Parasit., Australian Academy of Science, Canberra, p. 105 (Abstract)

Condé, B. (1976). Parastitism de Labridés de la région Coraibes par une planaire. Rev. fr Aquariol. Herp. 3: $23-24$

Flemming, L. C., Burt, M. D. B., Bacon, G. B. (1981). On some commensal turbellarians of the Canadian East Coast. Hydrobiologia 84: 131-137

Grizzle, J. M., Williams, E. H. (1985). Lesions of a rock beauty, Holocanthus tricolor (Bloch), from Puerto Rico. J. Fish. Dis. 8: $129-134$

Jägerskiöld, L. A. (1896). Ueber Micropharynx parasitica n. g. n. sp. Eine ectoparasitische Triclade. Ofervs. k. VetenskAkad. Forh. Stockh. 53: 707-714

Jennings, J. B. (1971). Parasitism and commensalism in the Turbellaria. Adv. Parasit. 9: 1-32

Jennings, J. B. (1981). Physiological adaptation to entosymbiosis in three species of graffillid rhabdocoels. Hydrobiologia $84: 147-153$

Jennings, J. B. (1985). Feeding and digestion in the aberrant planarian Bdellasimilis barwicki (Turbellaria: Tricladida: Procerodidae): an ectosymbiote of freshwater turtles in
Queensland and New South Wales. Aust. J. Zool. 33: $317-327$

Jennings, J. B., Phillips, J. I. (1978). Feeding and digestion in three entosymbiotic graffillid rhabdocoels from bivalve molluscs. Biol. Bull. mar. biol. Lab., Woods Hole 155: $542-562$

Kent, M. L. (1981). The life cycle and treatment of a turbelldrian disease of marine fish. Freshw. mar. Aq. Mag. 4: $11-13$

Kent, M. L., Olson, A. C. (1980). Interrelationships between a parasitic turbellarian and its marine fish hosts. Prog. Abs. 159: 55th Ann Meet., Am. Paras. Soc., p. 67

Kent, M. L., Olson, A. C. (1986). Interrelationships of a parasitic turbellarian (Paravortex sp.) (Graffillidae, Rhabdocoela) and its marine fish hosts. Fish. Path. 21: 65-72

Marcus, E. (1951). Turbellaria Brasileiros (9). Bolm. Fac. Filos. Ciènc. Univ. S Paulo 16: 5-216

Marcus, E. (1954). Turbellaria Brasileiros (11). Papeis. Dep Zoôl. S. Páù 1: 4 419489

Menitskii, Y. L. (1963). Structure and systematic position of the turbellarian Ichthyophaga subcutanea Syromjatnikova 1949, parasitising fish. Parazit. Sb. 21. 245-258. (Translation from Russian by Al Ahram Center for Scientific Translations, Cairo)

Palombi, A. (1926). Digenobothrium inerme nov. gen. nov. sp. (Crossocoela). Considerazioni sistematische sull'ordine degli Alloeocoela. Archo zool. ital. 11: 143-177

Pike, A. W., Burt, M. D. B. (1981). Paravortex karlingi sp. nov. from Cerastoma edule L., in Britain. Hydrobiologia 84: 23-30

Richardson, L. R. (1968). A new bdellourid-like triclad turbellarian ectoconsortic on Murray R. Chelonia. Proc. Linn. Soc. N. S. W 93: 90-97

Richardson, L. R. (1970). A note on Bdellasimilis barwicki and an indication of a second species (Turbellaria: Tricladida). Aust. Zool. 15: 400-402

Syromjatnikova, I. P. (1949). A new turbellarian parasitic in fish and called Ichthyophaga subcutanea. Dokl. Akad. Nauk SSSR 68: 805-808. (Russian)

Vogt, C. (1891). Sur le parasitisme transitoire d'un Turbéllariés triclade (Gunda sp.). C. r. Ass. fr. Advanc. Sci. 1891: $239-240$

Wardle, W. S. (1980). Occurrence of the symbiotic rhabdocoel flatworm Paravortex gemellipara in Cheasepeake Bay and Gulf of Mexico molluscs, with notes on its biology and geographic range. Estuaries 3: 84-88

Westblad, E. (1955). Marine 'Alloeocoels' (Turbellaria) from North Atlantic and Mediterranean coasts. I. Ark. Zool. 7 491-526

Wilhelmi, J. (1909). Fauna und Flora des Golfes von Neapel und der angrenzenden Meeresabschnitte. Monographie 33, R. Friedländer und Söhne, Berlin 